\title{
COMPREHENSIVE ASSESSMENT OF QUALITY AND SAFETY OF BERRY SAUCE WITH IODINE-CONTAINING ADDITIVE
}

\author{
Gregoriy Deynichenko \\ Department of Processes and Equipment of Food and Hotel and \\ Restaurant Industry named after M. I. Belyaev ${ }^{1}$ \\ deinychenkogv@ukr.net \\ Tamara Lystopad \\ Department of Processes and Equipment of Food and Hotel and \\ Restaurant Industry named after M. I. Belyaev ${ }^{1}$ \\ lystopad.tamara.88@gmail.com \\ Anna Novik \\ Department of food technology \\ anna.novik.82@ukr.net \\ Line Chernushenko \\ Department of food technology \\ Linechern@gmail.com \\ Andrii Farisieiev \\ Department of Food Technology $y^{2}$ \\ fara51289@gmail.com \\ Yuliia Matsuk \\ Department of Food Technology $y^{2}$ \\ lyly2006@ukr.net
}

Tatiana Kolisnychenko

Department of International Economic Relations, Regional Studies and Tourism

University of Customs and Finance

2/4 Volodymyr Vernadsky str., Dnipro, Ukraine, 49000

ktatyna1407@gmail.com

${ }^{1}$ Kharkiv State University of Food Technology and Trade

333 Klochkivska str., Kharkiv, Ukraine, 61051

${ }^{2}$ Oles Honchar Dnipropetrovsk National University

72 Gagarin ave., Dnipro, Ukraine, 49010

\footnotetext{
Abstract

One of the acute problems of our time is iodine deficiency in human nutrition, which is typical for both countries with economies in transition and economically developed ones. Today, about a third of the world's population live in conditions of natural iodine deficiency. The most common solution to iodine deficiency is salt iodization, but this can lead to excessive iodine intake. In addition, it is much healthier to eat organic iodine, which is found in large quantities in brown algae. It is the development of new types of food products using brown algae as a biologically active additive that is a new promising direction for solving the problem of insufficient iodine consumption.

Taking into account the relevance of solving the problem of iodine deficiency and the constantly growing demand for fruit and berry sauces, the technology of berry sauces based on blueberries, cranberries, dogwood, sea buckthorn and viburnum with the addition of brown algae has been developed. However, the mass introduction into production and consumption of the developed sauces will make a significant contribution to solving the global problem of insufficient consumption of organic iodine, requires research to establish their compliance with the typical quality and safety indicators for these products.

The physicochemical indicators of the developed berry sauces were investigated, confirming the high quality in terms of the content of soluble solids $-25.0 \ldots 28.5 \%$, the mass fraction of titratable acids $-1.9 \%$, and indicate the complete absence of mineral,
} 
vegetable and foreign substances in the product. It was found that the developed sauces with iodine-containing algal additive have high microbiological quality indicators when stored for up to 14 days, even without adding preservatives. The complete safety of the developed berry sauces was established in terms of the content of toxic elements, as well as the absence of genetically modified organisms in the finished product.

Keywords: berry sauces, quality indicators, safety, iodine-containing additive, algae.

DOI: $10.21303 / 2504-5695.2020 .001435$

\section{Introduction}

As evidenced by the materials of the Global Environment Outlook (GEO-6) of the United Nations Environment Program, the overall environmental situation in the world is deteriorating from year to year. Unsustainable production and consumption patterns and trends, inequality, coupled with increased resource use driven by population growth and urbanization, threaten the ecological state of the planet necessary to achieve sustainable development [1].

In the context of the constant deterioration of the ecological situation in the world, special attention of mankind should be shown to its nutrition. Scientists see the solution to this issue through the introduction of adequate nutrition, including through the development of new products for daily consumption. This category primarily includes sauces, among the main tasks of which are improving the organoleptic properties of ready-made meals and increasing their nutritional and biological value [2].

At the same time, the problem of iodine deficiency in human nutrition is acute in the world, despite the fact that the daily requirement for this microelement ranges from $90 \mu \mathrm{g}$ for children under 5 years of age to $250 \mu \mathrm{g}$ for pregnant and lactating women [3]. The indispensability of iodine in the life of the human body is explained by its participation in the structure of thyroid hormones. In addition, iodine participates in and controls metabolism, increases immunity and the activity of some sex hormones [4].

Iodine deficiency is a public health problem in 54 countries, both in marginalized economies and in industrialized regions of the world. Today, about 2 billion people around the world live in conditions of natural iodine deficiency, incl. one third of school children. Minor iodine deficiency is still observed in about $50 \%$ of continental Europe, and the problem has reappeared in the USA and Australia [5, 6].

The problem of iodine deficiency in the human diet can be eliminated either by introducing iodine-containing components into the recipe of existing dishes, or by developing new types of food products of increased biological value $[7,8]$.

The most effective solutions to the problem of iodine deficiency include mass and individual prevention of iodine deficiency with iodized salt and iodine medications, respectively. In countries that have eliminated iodine deficiency, the general mandatory iodization of salt is enshrined in legislation [9]. However, general salt iodization can also lead to excessive iodine intake [10]. About $70 \%$ of households in low-income countries worldwide use only iodized salt in their diets [11].

It is well known that the use of organic iodine has a number of advantages over artificial iodization of food. Organic iodine is found in the largest quantities in hydrobionts, namely in brown algae, where its content can reach hundreds of milligrams per gram [12-17]. This means that even a small amount of these algae in the form of a food additive can have a significant impact on solving the problem of iodine deficiency. It should also be noted that in addition to iodine, algal raw materials are rich in proteins, polysaccharides, vitamins, macro- and microelements [14-16]. Such a rich composition of algae, in addition to solving the problem of iodine deficiency, allows to establish metabolism, reduces the accumulation of radionuclides and salts of heavy metals, and has a positive effect on the functioning of most body systems [14, 17]. All of the above contributes to the fact that algal raw materials are becoming an increasingly popular food additive in the development of new food products [18].

Such products are fruit and berry sauces, which are becoming more and more popular both among ordinary consumers and among manufacturers. Taking into account the growing demand for berry sauces and the urgency of solving the problem of iodine deficiency, the technologies of 
berry sauces have been developed: blueberry-cranberry with viburnum juice, cornelian-blueberry with viburnum juice and blueberry-sea buckthorn with viburnum juice, additionally enriched with iodine-containing additives made from such brown algae as kelp, undaria pinnate and fucus [17, 19-21]. According to preliminary calculations, even the consumption of $100 \mathrm{~g}$ of such a sauce will satisfy a person's daily need for iodine.

However, in addition to the beneficial effect on the body, food products must be completely safe for human consumption, to which not all producers and consumers pay attention, preferring not the quality of food products, but their price. Therefore, compliance with high quality and environmental safety of food is an acute issue for consumers in each country [22]. Taking into account the fact that the anthropogenic impact of human activity on nature has approached a critical point, and the planet's ecology is deteriorating more and more, which is facilitated by radiation, noise, chemical and other pollution and household waste [23], and food contains toxic elements [24], the task of determining the compliance of the developed product with the requirements of regulatory documents is extremely necessary.

Based on the above, the aim of the article can be formulated, which is to comprehensively assess the quality of berry sauces with iodine-containing additives according to typical quality and safety indicators for the developed type of product.

To achieve this aim, it is necessary to solve the following objectives:

- to investigate the physical and chemical indicators of the quality of the developed berry sauces;

- to conduct a microbiological analysis of the developed berry sauces;

- to investigate the safety of the developed berry sauces in terms of the content of toxic elements, pesticides and radionuclides;

- to investigate the presence of genetically modified organisms in the developed berry sauces.

\section{Materials and Methods}

Wild and cultivated blueberries, dogwood, cranberries, sea buckthorn and viburnum were used as the main raw material for the preparation of the studied sauces. On their basis, technologies of three sauces were developed: cornelian-blueberry, blueberry-cranberry, blueberry-sea buckthorn. The role of iodine-containing algal supplements is performed by dry brown algae in the following concentrations: cirrus undaria $-3 \%$; fucus $-3 \%, 5 \%$; kelp $-3 \%, 5 \%$ and $8 \%$. In addition, the technology of preparation of each sauce involves the addition of viburnum juice [20].

The preparation of sauces and direct research were carried out in laboratory conditions on the basis of the Oles Honchar Dnipro National University and the Kharkiv State University of Food Technology and Trade, the determination of the content of toxic elements was carried out on the basis of the State Enterprise "Dnipro Regional State Scientific and Technical Center for Standardization, Metrology and Certification".

Sampling and preparation of samples for laboratory analyzes were carried out in accordance with the requirements of ISO 7002:1986. In the study of physical and chemical parameters, the following were determined: mass fraction of soluble solids (SS) - by the refractometric method according to ISO 2173:2003 (since the developed sauces are distinguished by bright colors at the stage of sample preparation, the prototypes were diluted with distilled water twice) the mass fraction of titratable acids - according to ISO 750:1998; mass fraction of mineral impurities (MI) - by the flotation method according to ISO 762:2003 (the essence of the method is to see the product by flotation of insoluble mineral impurities, followed by solubilization of the resulting sediment and weighing it).

Determination of the content of toxic elements (lead, cadmium, arsenic, mercury) was carried out according to the MP SCSMC method 9/32-00 taking into account the requirements of ISO 6633:1984, ISO 6561-2:2005, ISO 6634:1982, ISO 6637:1984, which is included in the current sphere of accreditation of the laboratory of the Testing and Research Center for Food and Industrial Products of the State Enterprise "Dnipro Regional State Scientific and Technical Center for Standardization, Metrology and Certification". At the time of the research, the laboratories of TRC 
FIP were accredited according to the international standard ISO/IEC 17025 (certificate of accreditation of the NAAU No. $2 \mathrm{H} 047$ dated 06.01.2017, valid until 16.06.2019). The measurement technique is implemented on an atomic absorption spectrophotometer with flame and electrothermal atomization; a device for generating steam is also used. Vapor generation is an extremely sensitive procedure used to determine the mercury and arsenic content of samples. The detection limit for the content of toxic elements is for: lead $-0.0040 \mathrm{mg} / \mathrm{kg}$, cadmium $-0.0010 \mathrm{mg} / \mathrm{kg}$, arsenic $0.0010 \mathrm{mg} / \mathrm{kg}$, mercury $-0.0001 \mathrm{mg} / \mathrm{kg}$.

The determination of the pesticide content was carried out for compliance with DSanPiN 8.8.1.2.3.4-000 according to DSTU EN 12939-3: 2003 on the basis of the Testing Center of the State Enterprise "Zaporizhzhia Scientific and Production Center for Standardization, Metrology and Certification" (SE "Zaporizhzhiastandartmetrologiya") accredited by the national agency for accreditation of Ukraine for compliance with DSTU ISO/IEC 17025:2006 (certificate of accreditation No. 2H661 dated 28.12.2018, valid until 27.12.2023).

The determination of the level of radionuclides $\left({ }^{137} \mathrm{Cs}\right.$ and $\left.{ }^{90} \mathrm{Sr}\right)$ was carried out for compliance with the requirements of GN 6.6.1.1-130-2006 "Permissible levels of ${ }^{137} \mathrm{Cs}$ and ${ }^{90} \mathrm{Sr}$ radionuclides in food and drinking water" on the basis of the examination, certification and declaration department of the Volyn Chamber of Commerce and Industry.

Sampling for microbiological analysis was carried out according to ISO/TS 17728:2015, sample preparation - according to ISO 6887-1:2017. The tests were carried out according to the following microbiological indicators: mesophilic aerobic and facultative anaerobic microorganisms (MAFanM) - according to ISO 4831:2006; E. coli bacteria - according to ISO 7251:2005; molds and yeasts - according to ISO 21527-2:2008; lactic acid bacteria - according to ISO 15214:1998. Determination of the presence/absence of pathogenic microorganisms (including bacteria of the genus Salmonella) was carried out in accordance with ISO 6579-1:2017/AMD 1:2020.

Studies to determine the content of genetically modified organisms GMO in berry sauces were carried out using the method of polymerase chain reaction (PCR) with detection of research results in real time. Sampling and studies of the presence or absence of GMOs in the composition of the developed sauces were carried out in accordance with international requirements and standards - CEN/TS 15568:2006, ISO 21569:2005/AMD 1:2013, ISO 24276:2006/AMD 1:2013 and recommendations [ 25]. The study involves the sequential conduct of two analyzes - qualitative and quantitative. When establishing the fact of the presence of GMOs in the composition of the product, quantitative analysis allows to establish their actual amount. It should be borne in mind that EU requirements allow the presence of GMOs in food in the amount of up to $0.9 \%$ by weight of the protein that is part of the product itself. Therefore, for the experiment, not an average sample is used, but an analytical sample that contains all the components of the finished product.

\section{Results and Discussion}

In order to obtain data on the quality of the developed sauces, a study of physical and chemical parameters was carried out. It was found that all sauces are characterized by a high content of soluble solids. So the content of soluble solids in blueberry-sea buckthorn sauce with viburnum juice varies from $25.0 \%$ to $26.0 \%$, depending on the amount of iodine-containing algal supplements. For blueberry-cranberry sauce with viburnum juice, this indicator varies from $27.0 \%$ to $27.5 \%$, and for cornelian-blueberry sauce with viburnum juice - from $27.5 \%$ to $28.5 \%$, respectively. In addition, soluble solids are in an easy-to-digest form.

Based on the requirements for berry sauces (DSTU 6087:2009), the mass fraction of mineral impurities should not exceed $0.03 \%$. According to the results of the studies, the complete absence of impurities of various origins in the developed sauces was established.

The mass fraction of titratable acids that take part in the formation of the taste and aroma of the developed sauces does not exceed $1.9 \%$. It should be noted that the addition of algal raw materials has practically no effect on this indicator, compared to sauces without additives. The presence of such a quantity of acids is due to the recipe composition of sauces, the main raw materials of which in their natural form are also characterized by high acidity. Based on the results obtained, it can be assumed that the own food acids of the original berry raw material may be sufficient to pre- 
serve the microbiological purity of the product, which will allow avoiding the addition of additional preservatives to the formulation of the developed sauces.

The safety level of sauces is characterized by their microbiological and toxicological indicators. The study of safety indicators was carried out on the example of blueberry-cranberry sauce with viburnum juice with the addition of algal raw materials.

The addition of different amounts of algal additives to the sauce did not show significant differences in the number of detected microorganisms. The summary results of studies of the dynamics of microbiological safety of blueberry-cranberry sauce with viburnum juice with the addition of algal raw materials are shown in Table $\mathbf{1}$.

Table 1

Dynamics of microbiological indicators

\begin{tabular}{|c|c|c|c|c|c|}
\hline \multirow{2}{*}{$\begin{array}{l}\text { Indicators designation according to } \\
\text { the regulatory document }\end{array}$} & \multicolumn{5}{|c|}{ Storage term } \\
\hline & $\begin{array}{l}\text { After manu- } \\
\text { facturing }\end{array}$ & 1 day & 7 day & 10 day & 14 day \\
\hline $\begin{array}{l}\text { The number of mesophilic aerobic and facultative anaerobic } \\
\text { microorganisms, CFU in } 1 \mathrm{~g} \text { of the product, no more: }\end{array}$ & $<1.0 \times 10$ & $<1.0 \times 10$ & $\leq 1.0 \times 10$ & $1.0 \times 10$ & $\geq 1.0 \times 10^{2}$ \\
\hline Coliforms in $1 \mathrm{~g}$ of product: & $\mathrm{N} / \mathrm{D} *$ & $\mathrm{~N} / \mathrm{D}$ & $\mathrm{N} / \mathrm{D}$ & $\mathrm{N} / \mathrm{D}$ & $\mathrm{N} / \mathrm{D}$ \\
\hline Molds, CFU in $1 \mathrm{~g}$ of product, no more: & $<1.0 \times 10$ & $<1.0 \times 10$ & $<1.0 \times 10$ & $<1.0 \times 10$ & $<1.0 \times 10$ \\
\hline Yeast, CFU in $1 \mathrm{~g}$ of product, no more: & $<1.0 \times 10$ & $<1.0 \times 10$ & $<1.0 \times 10$ & $<1.0 \times 10$ & $\leq 1.0 \times 10$ \\
\hline The number of lactic acid bacteria, CFU in $1 \mathrm{~g}$ of the product: & $\mathrm{N} / \mathrm{D}$ & $\mathrm{N} / \mathrm{D}$ & $\mathrm{N} / \mathrm{D}$ & $\mathrm{N} / \mathrm{D}$ & $\mathrm{N} / \mathrm{D}$ \\
\hline $\begin{array}{l}\text { Pathogenic microorganisms (including bacteria of the genus } \\
\text { Salmonella) in } 25 \mathrm{~g} \text { of product: }\end{array}$ & $\mathrm{N} / \mathrm{D}$ & $\mathrm{N} / \mathrm{D}$ & $\mathrm{N} / \mathrm{D}$ & N/D & $\mathrm{N} / \mathrm{D}$ \\
\hline
\end{tabular}

The results obtained indicate a high safety of the developed berry sauces with the addition of algal raw materials for all microbiological indicators, even during storage for 14 days. Such results indicate the inexpediency of adding components that extend the shelf life of the developed berry sauces, including preservatives and antibiotics. In addition, rheological studies carried out earlier made it possible to establish that the introduction of additional stabilizers into the composition of the developed sauces does not make sense, since the own pectin substances of berry raw materials and algal additives are sufficient to stabilize the system. Thus, samples of sauces with the addition of up to $8 \%$ of hydrated kelp and $3 \%$ of fucus and undaria plumose show similar dynamics in comparison with control samples of sauces made according to existing technologies based on the most common stabilizers. Thus, the proposed technology of berry sauces differs from the existing analogues by its complete naturalness.

To confirm the obtained research results and confirm the appropriate quality and safety of sauces to regulatory documents, such as blueberry-cranberry sauce with viburnum juice and the maximum content of algal raw materials $-8 \%$ kelp - was sent for an independent examination to the Testing and Research Center for Food and Industrial Products of the State enterprises "Dnipro Regional State Scientific and Technical Center for Standardization, Metrology and Certification”.

An independent examination of the sauce sample was carried out for compliance with the requirements of the state standard for sauces (DSTU 6087:2009) and microbiological criteria for establishing food safety indicators (Order of the Ministry of Health of Ukraine dated 19.07.2020 No. 548).

An extract from the sample test report is shown in Table 2.

From the results of Table 2, the reliability of the results of studies of physical and chemical indicators and safety indicators of the developed berry sauces is obvious. In addition, the sauces produced using the proposed technology meet the requirements of regulatory documents. It can be noted that the content of toxic elements in the developed sauces is at a very low level, and from 
30 to 200 times lower than the maximum permissible, which may indicate the complete safety of this product for the human body.

Table 2

Independent examination results

\begin{tabular}{|c|c|c|c|c|}
\hline \multirow{2}{*}{ Indicator } & \multirow{2}{*}{$\begin{array}{l}\text { Values of indicators } \\
\text { according to the nor- } \\
\text { mative document }\end{array}$} & \multirow{2}{*}{$\begin{array}{l}\text { Values of indicators } \\
\text { according to the nor- } \\
\text { mative document }\end{array}$} & \multicolumn{2}{|c|}{$\begin{array}{c}\text { Number of product } \\
\text { samples }\end{array}$} \\
\hline & & & $\begin{array}{l}\text { tested, } \\
\text { kg }\end{array}$ & $\begin{array}{l}\text { not corre- } \\
\text { sponding, } k g\end{array}$ \\
\hline Mass fraction of soluble solids, $\%$, not less: & $19-23$ & $27.5 \Delta \pm 0.5$ & 1 & - \\
\hline $\begin{array}{l}\text { Mass fraction of mineral impurities, } \% \text {, not more } \\
\text { than: }\end{array}$ & 0.03 & not detected & 1 & - \\
\hline Vegetable impurities, $\%$ & not allowed & not detected & 1 & - \\
\hline Impurities, $\%$ & not allowed & not detected & 1 & - \\
\hline $\begin{array}{l}\text { The number of mesophilic aerobic and facultative } \\
\text { anaerobic microorganisms, CFU in } 1 \mathrm{~g} \text { of the } \\
\text { product, no more: }\end{array}$ & $1.0 \times 10^{2}$ & $1.0 \times 10$ & 1 & - \\
\hline Coliforms in $1 \mathrm{~g}$ of product: & not allowed & not detected & 1 & - \\
\hline Molds, CFU in $1 \mathrm{~g}$ of product, no more: & 50 & $<1,0 \times 10$ & 1 & - \\
\hline Yeast, CFU in $1 \mathrm{~g}$ of product, no more: & 50 & $<1,0 \times 10$ & 1 & - \\
\hline $\begin{array}{l}\text { The number of lactic acid bacteria, CFU in } 1 \mathrm{~g} \text { of } \\
\text { the product: }\end{array}$ & not allowed & not detected & 1 & - \\
\hline $\begin{array}{l}\text { Pathogenic microorganisms (including bacteria of } \\
\text { the genus Salmonella) in } 25 \mathrm{~g} \text { of product }\end{array}$ & not allowed & not detected & 1 & - \\
\hline \multicolumn{5}{|l|}{ Mass fraction of toxic elements, $\mathrm{mg} / \mathrm{kg}$, no more: } \\
\hline lead & 0,40 & $<0.0040$ & 1 & - \\
\hline cadmium & 0,03 & $<0.0010$ & 1 & - \\
\hline arsenic & 0,20 & $<0.0010$ & 1 & - \\
\hline mercury & 0,02 & $<0.0001$ & 1 & - \\
\hline
\end{tabular}

To confirm the safety of ready-made berry sauces in terms of the content of radionuclides and pesticides, a study of their presence in the feedstock was carried out. According to the results of studies of the content of pesticides (test report No. 22/1524-G dated 25.07.2019, issued by the testing center of the State Enterprise "Zaporizhzhia Scientific and Production Center for Standardization, Metrology and Certification"), their complete absence in the studied samples of raw materials was established. Based on the results obtained, it can be argued about the complete absence of pesticides in ready-made berry sauces.

According to GN 6.6.1.1-130-2006, the permissible level of radionuclides $\left({ }^{137} \mathrm{Cs}\right.$ and $\left.{ }^{90} \mathrm{Sr}\right)$ in wild berries is $500 \mathrm{~Bq} / \mathrm{kg}$ and $50 \mathrm{~Bq} / \mathrm{kg}$, in dried seaweed $600 \mathrm{~Bq} / \mathrm{kg}$ and $200 \mathrm{~Bq} / \mathrm{kg}$, respectively. The conducted studies have established the full compliance of the studied feedstock for the production of berry sauces with iodine-containing additives in terms of the content of radionuclides, the content of ${ }^{137} \mathrm{Cs}$ is $<7.63 \mathrm{~Bq} / \mathrm{kg},{ }^{90} \mathrm{Sr}-18.8 \pm 9.39 \mathrm{~Bq} / \mathrm{kg}$ (Certificate of radiation research of objects (products) No. 959 dated 07.01.2019 issued by the Volyn Chamber of Commerce and Industry). The results obtained allow to assert that they are prepared berry sauces completely safe for humans with a content of radionuclides.

Studies to determine the content of GMOs in berry sauces using the PCR method with the detection of research results in real time at the analysis stage showed the complete absence of 
GMOs in the samples under study. That is, it can be argued that the developed berry sauces with the addition of iodine-containing algal raw materials are potentially not transgenic and do not contain GMO components in their composition.

\section{Conclusions}

The physicochemical parameters of the developed berry sauces with the addition of iodine-containing additives, which show compliance with the requirements of regulatory documents for the content of soluble solids (24.5...28.5\%), and the complete absence of mineral, extraneous and vegetable impurities, have been studied. The mass fraction of titratable acids in the composition of ready-made sauces is $1.9 \%$, which is explained by the recipe composition and will allow to move away from the addition of additional preservatives.

It is established that the developed berry sauces have a high degree of microbiological safety in all respects, including the content of pathogenic organisms, even during storage for up to 14 days.

The developed berry sauces with the addition of algal raw materials do not contain toxic elements in their composition, regardless of their composition, the type of algal additive and its amount.

Raw materials for the production of berry sauces with iodine-containing algal additive do not contain pesticides and contain an acceptable level of radionuclides.

The complete absence of GMOs in the composition of the developed berry sauces enriched with iodine is found.

Thus, according to the results of the research, the full compliance of the developed berry sauces with the addition of algal raw materials is confirmed in terms of physicochemical, microbiological, toxicological indicators and the content of GMOs in their composition, their safety for human consumption is established.

\section{References}

[1] Global Environment Outlook - GEO-6: Healthy Planet, Healthy People (2019). Cambridge University Press. doi: https:// doi.org/10.1017/9781108627146

[2] Balatska, N. Yu. (2008). Marketynhovi doslidzhennia na rynku solodkykh sousiv. Ekonomichna stratehiya i perspektyvy rozvytku sfery torhivli ta posluh, 2 (8), 282-286.

[3] Assessment of iodine deficiency disorders and monitoring their elimination: a guide for programme managers (2007). World Health Organization. Available at: https://apps.who.int/iris/handle/10665/43781

[4] Hryshyna, E. O., Tytarenko, A. V. (2011). Vplyv vitaminiv ta mineraliv na orhanizm liudyny. Naukovi zapysky KNTU, 11, 240-246.

[5] Platonova, N. M. (2015). Iodine deficiency: current status. Clinical and experimental thyroidology, 11 (1), 12-21. doi: https:// doi.org/10.14341/ket2015112-21

[6] Hernando, V.-U., Anilza, B.-P., Hernan, S.-T. C. (2015). Iodine Deficiency Disorders. Journal of Thyroid Disorders \& Therapy, 4 (1). doi: https://doi.org/10.4172/2167-7948.1000172

[7] Alekseeva, E. L. (2011). Sousy - tsennoe dopolnenie k gotovym blyudam. Advances in current natural sciences, 7, 67.

[8] Hodyreva, Z. R., Romanova, M. E. (2011). Razrabotka novyh vidov sousov. Polzunovskiy vestnik, 3/2, 175-179.

[9] Andersson, M., de Benoist, B., Rogers, L. (2010). Epidemiology of iodine deficiency: Salt iodisation and iodine status. Best Practice \& Research Clinical Endocrinology \& Metabolism, 24 (1), 1-11. doi: https://doi.org/10.1016/j.beem.2009.08.005

[10] Zimmermann, M. (2013). Iodine Deficiency and Excess in Children: Worldwide Status in 2013. Endocrine Practice, 19 (5), 839-846. doi: https://doi.org/10.4158/ep13180.ra

[11] Pearce, E. N., Andersson, M., Zimmermann, M. B. (2013). Global Iodine Nutrition: Where Do We Stand in 2013? Thyroid, 23 (5), 523-528. doi: https://doi.org/10.1089/thy.2013.0128

[12] Korzun, V. N., Sahlo, V. I., Parats, A. M. (2004). Kharchovi produkty z vodorostiamy yak zasib minimizatsiyi diyi radiatsiyi ta endemiyi. Problemy kharchuvannia, 1 (2), 29-34.

[13] Yeh, T. S., Hung, N. H., Lin, T. C. (2014). Analysis of iodine content in seaweed by GC-ECD and estimation of iodine intake. Journal of Food and Drug Analysis, 22 (2), 189-196. doi: https://doi.org/10.1016/j.jfda.2014.01.014

[14] Fleurence, J., Morançais, M., Dumay, J. (2018). Seaweed proteins. Proteins in Food Processing, 245-262. doi: https://doi.org/ 10.1016/b978-0-08-100722-8.00010-3 
[15] Roohinejad, S., Koubaa, M., Barba, F. J., Saljoughian, S., Amid, M., Greiner, R. (2017). Application of seaweeds to develop new food products with enhanced shelf-life, quality and health-related beneficial properties. Food Research International, 99, 1066-1083. doi: https://doi.org/10.1016/j.foodres.2016.08.016

[16] Barba, F. J. (2017). Microalgae and seaweeds for food applications: Challenges and perspectives. Food Research International, 99, 969-970. doi: https://doi.org/10.1016/j.foodres.2016.12.022

[17] Thanigaivel, S., Chandrasekaran, N., Mukherjee, A., Thomas, J. (2016). Seaweeds as an alternative therapeutic source for aquatic disease management. Aquaculture, 464, 529-536. doi: https://doi.org/10.1016/j.aquaculture.2016.08.001

[18] Andersson, M., de Benoist, B., Darnton-Hill, I., Delange, F. (Eds.) (2007). Iodine deficiency in Europe: A continuing public health problem. World Health Organization, 86. Available at: https://www.who.int/nutrition/publications/VMNIS_Iodine_deficiency_in_Europe.pdf

[19] Deinychenko, H. V., Lystopad, T. S., Kolisnychenko, T. O. (2018). Obgruntuvannia dotsilnosti vykorystannia vodorostevoi syrovyny pry vyhotovlenni sousiv iz dykoroslykh ta kultyvovanykh yahid. Pratsi Tavriyskoho derzhavnoho ahrotekhnolohichnoho universytetu, 1 (18), 29-36.

[20] Deinychenko, G., Kolisnychenko, T., Lystopad, T. (2018). Development of technology of berry sauces with iodine-containing additives taking into account their influence on organoleptic parameters. Scientific Messenger of LNU of Veterinary Medicine and Biotechnologies, 20 (85), 107-113. doi: https://doi.org/10.15421/nvlvet8520

[21] Peresichnyi, M. I., Kravchenko, M. F., Hryhorenko, O. M. (1999). Tekhnolohiya vyrobnytstva produktsiyi hromadskoho kharchuvannia radiozakhysnoi diyi - teoriya ta praktyka. Kyiv: Medykol MNITs, BIO-EKOS, 231.

[22] Pashniuk, L. O. (2012). Food industry of Ukraine: state, tendencies and perspectives of development. Ekonomichnyi chasopys-XXI, 9-10, 60-63.

[23] Hasbulatov, R. V. (2014). Mizhnarodni ekonomichni vidnosyny. Available at: https://stud.com.ua/54478/ekonomika/mizhnarodni_ekonomichni_vidnosini

[24] Dubinina, A. A., Maliuk, L. P., Seliutina, H. A., Shaporova, T. M. (2005). Tovaroznavchi aspekty pidvyshchennia bezpeky kharchovykh produktiv. Kyiv: Profesional, 173.

[25] 2004/787/EC: Commission Recommendation of 4 October 2004 on technical guidance for sampling and detection of genetically modified organisms and material produced from genetically modified organisms as or in products in the context of Regulation (EC) No 1830/2003Text with EEA relevance (2004). Official Journal of the European Union, 348, 18-26. 